\title{
Research on 5S Site Management of Electric Power Infrastructure Projects Based on Game Theory
}

\author{
Jianna Zhao \\ Department of Economics and Management, North China \\ Electric Power University, China \\ No.689 Huadian Road, Beishi district, Baoding, 071003, \\ China \\ zhjnzhf@163.com
}

\begin{abstract}
Activities of electric infrastructure projects are regarded as a system included production, plan, logistics and information flow. And the reasonable running of the system is very important to complete an engineering project. In all activities, site management is the most basic process, and there hide a lot of problems. In order to find the efficiency and low cost operation in the power infrastructure project, we play the game between the enterprise and the employees and analyze the payoff from the angle of game theory. Constantly optimize the management method, making the site management more effective, improve the quality of enterprise construction, improve efficiency and reduce the occurrence of accidents.
\end{abstract}

Keywords—game theory; electric infrastructure projects; $5 S$ site management

\section{INTRODUCTION}

With the rapid development of economy in our country, the electric power resource has become one of the important conditions which restrict the economic development of our country. The scale of construction increase step by step. And the requirements of the infrastructure construction management become higher. $5 \mathrm{~S}$ site management standard make the working system standardize, improve the poor working environment, and then improve the work efficiency, achieve the goal of improving the quality of the product. In this paper, the implementation of $5 \mathrm{~S}$ site management has been discussed, considering the respective interests of enterprises and employees. And at last, find the final result that benefits both parties by the game theory method. Providing a new method and path for us to strengthen management, reduce costs, improve quality, and reduce the risk.

\section{5S SITE MANAGEMENT}

Site management is an important part of enterprise management, and it is also the overall embodiment of enterprise management level. It is necessary for enterprises to strengthen site management. This can enhance the quality of the project.

\section{A. The content of $5 S$ site management}

$5 \mathrm{~S}$ is the abbreviation of SEIRI, SEITON, SEISO, SEIKETSU and SHITSUKE. The object of $5 \mathrm{~S}$ is environment. It makes a comprehensive consideration to the overall situation

\author{
Xuan Du \\ Department of Economics and Management, North China \\ Electric Power University, China \\ No.689 Huadian Road, Beishi district, Baoding, 071003, \\ China \\ dx address@163.com
}

of the site, and makes feasible plans and measures to achieve the standardization management.

SEIRI means distinguish between what is needed and not. There are only useful things leaved in the workplace. Clear unnecessary items.

SEITON means give everything a fixed position. Neatly arrange them and mark the quantity. We can easily find what we need. Reduce the search time.

SEISO means keep the working environment clean to prevent the occurrence of pollution. This can Reduce industrial damage, create a good working environment, keep a high quality of products and make employees a good mood.

SEIKETSU means make all of these be institutionalized. In order to keep all of the achievements that has already been achieved.

SHITSUKE means to develop good working habits. Eventually form a good corporate culture.

\section{B. The advantages of $5 S$ site management}

5S management is the entry point to a quality assurance system. Start with environmental management to develop a good habit for every employee. Form corporate culture of the implementation of quality assurance.

The implement of $5 \mathrm{~S}$ can give employees a clean construction site, which can make them feel comfortable. It also can influence the working atmosphere. Second, a lot of time is saved during looking for tools. Third, we can easily find the dangerous place and avoid it. And then, standardized operation makes quality more secure. The quality of electric project need to reaches a high level to ensure normal living of people and the steady development of economy. So 5S site management of electric infrastructure project is particularly important.

\section{GAME BETWEEN MANAGEMENT AND EMPLOYEES}

Discuss the implementation of $5 \mathrm{~S}$ site management, based on the respective interests of enterprises and employees. Construct the model of game theory, and analysis the result of game theory. 


\section{A. Model of game theory}

The complete information static game theory supposes that players have complete information. Each player has a complete understanding of the payoff of the other players. Players take action at the same time. Finally find out the Nash equilibrium between the players. Establish a complete information static game model between enterprise management and employees, with the common knowledge of all rational players. The paper makes the following assumptions:

Enterprise management chooses not to implement the $5 \mathrm{~S}$ site management, employees to consciously implement the $5 \mathrm{~S}$ site management. Cost C1, achieve W1. Enterprise management cost $\mathrm{C} 2$ when choosing to implement the $5 \mathrm{~S}$ site management. Employees implement the $5 \mathrm{~S}$ site management which can make enterprise increase W2 income and make themselves get the reward of $\mathrm{W} 3$. The penalty for employees which are not implementation is $\mathrm{C} 3$. $\mathrm{C} 3>\mathrm{C} 1, \mathrm{~W} 1>\mathrm{W} 2-\mathrm{C} 2$, $\mathrm{W} 2>\mathrm{C} 2, \mathrm{~W} 3>\mathrm{C} 1$.

According to the above assumptions, establish a complete information static game model between enterprise management and employees. Regard enterprise management and the employees as the two players. The strategy of employee is to obey or disobey. The strategy of enterprise management is to implement or ignore. Payment matrix is as follows:

TABLE I. THE PAYOFF BETWEEN ENTERPRISE MANAGEMENT AND EMPLOYEES

\begin{tabular}{|c|c|c|c|}
\hline \multicolumn{2}{|c|}{} & \multicolumn{2}{c|}{ employees } \\
\cline { 3 - 4 } \multicolumn{2}{|c|}{} & obey & disobey \\
\hline \multirow{2}{*}{$\begin{array}{c}\text { enterprise } \\
\text { management }\end{array}$} & implement & $\mathrm{W} 2-\mathrm{C} 2,-\mathrm{C} 1+\mathrm{W} 3$ & $-\mathrm{C} 2,-\mathrm{C} 3$ \\
\cline { 2 - 4 } & ignore & $\mathrm{W} 1,-\mathrm{C} 1$ & 0,0 \\
\hline
\end{tabular}

B. The analysis of result

\section{1) One time game}

According to the streak method, we can reach out the payoff of Nash equilibrium between enterprise management and employees is (ignore, disobey). In the one-time game theory, both the enterprise and the employees are seeking maximal benefits based on the rational assumption. But this choice does not achieve the Pareto optimal. At this time, players have not reached the maximum benefits. The Pareto optimal payoff between enterprise management and employees is (implement, obey). This is the best combination of the players. Therefore, in this game Nash equilibrium does not lead to Pareto optimal.

\section{2) Finitely repeated games}

Finitely repeated games usually use the reverse push to analyze the process of game. If the players clearly cooperate to the last time, the future will not repeat the game. There is no difference between the last period of the game and one time game. The deception and breach of the players are not likely to be retaliation, so the final period of the dominant strategy of a single player is not to cooperate. Push back to the previous period, the result is the same to one time game.

\section{3) Infinitely repeated games}

There is not exist a last stage of the game can be used as the last game in infinite repeated game. Reverse push method is invalid. There is always the chance of revenge in the infinite repeated game. One can avow that he never cooperate with other players again. They will suffer long-term heavy losses. So, each player will not take the act of breach or fraud. Game can reach the Pareto optimal.

\section{GAME BETWEEN SPECIAL TEAM AND EMPLOYEES}

Because of the inexistence of the infinite repeated game, we try to realize the maximum benefit by cooperation and the punishment of noncooperation.

\section{A. Model of game theory}

The paper makes the following assumptions:

It may cost $\mathrm{C} 0$ and achieve $\mathrm{L} 1$ to the enterprise if employees implement the $5 \mathrm{~S}$ site management or they do not implement but correct. Employees themselves may get the reward of L0. Employees are not implement the $5 \mathrm{~S}$ site management may cost $\mathrm{C}$, punish $\mathrm{X}$ when they are checked. Special team need $\mathrm{K}$ to check. C0 $>\mathrm{C}, \mathrm{K}>\mathrm{X}, \mathrm{L} 1>\mathrm{K}, \mathrm{L} 0>\mathrm{C} 0$.

The probability of special team to inspect implementation is P. The probability of mistaken obey the rule for not obey the rule is $\mathrm{U}$. The probability of employees implement the $5 \mathrm{~S}$ site management is V. The probability of employees being found not to obey the rules and do not correct is $\mathrm{W}$.

According to the above assumptions, establish a complete information static game model between special team and employees. Regard special team and the employees as the two players. Then come to the Nash equilibrium.

The pure strategy space of special team is:

A1: Active supervisions and get the correct conclusion

A2: Active supervisions but get the wrong conclusion

A3: Not supervise

The probability of each strategy is:

$\mathrm{S} 1=\{\mathrm{P}(1-\mathrm{U}), \mathrm{PU},(1-\mathrm{P})\}$

The pure strategy space of employees is:

B1: implement the $5 \mathrm{~S}$ site management

B2: do not implement but correct

B3: do not implement and not correct

The probability of each strategy is:

$\mathrm{S} 2=\{\mathrm{V},(1-\mathrm{V})(1-\mathrm{W}),(1-\mathrm{V}) \mathrm{W}\}$

Payment matrix is as follows: 
TABLE II. THE PAYOFF BETWEEN SPECIAL TEAM AND EMPLOYEES

\begin{tabular}{|c|c|c|c|c|c|}
\hline \multicolumn{2}{|c}{} & \multicolumn{3}{c|}{ employees } \\
\cline { 3 - 6 } & & $B 1$ & B2 & B3 \\
\hline \multirow{4}{*}{$\begin{array}{c}\text { special } \\
\text { team }\end{array}$} & $A 1$ & $P(1-U)$ & $-\mathrm{K}+\mathrm{L} 1,-\mathrm{C} 0+\mathrm{L} 0$ & $\mathrm{X}-\mathrm{K}+\mathrm{L} 1,-\mathrm{C} 0-\mathrm{X}$ & $\begin{array}{c}-\mathrm{K}+\mathrm{X},-\mathrm{C}- \\
\mathrm{X}\end{array}$ \\
\cline { 2 - 6 } & $\boldsymbol{A 2}$ & $\boldsymbol{P U}$ & $-\mathrm{K}+\mathrm{L} 1,-\mathrm{C} 0+\mathrm{L} 0$ & $-\mathrm{K},-\mathrm{C}+\mathrm{L} 0$ & $-\mathrm{K},-\mathrm{C}+\mathrm{L} 0$ \\
\cline { 2 - 6 } & $A 3$ & $\mathbf{1 - P}$ & $\mathrm{L} 1,-\mathrm{C} 0$ & $0,-\mathrm{C}$ & $0,-\mathrm{C}$ \\
\hline
\end{tabular}

\section{B. The analysis of result}

1) Pure Strategy Nash Equilibrium:

According to the streak method, we can reach out the payoff of Nash equilibrium between special team and employees is (A3, B3). If the special team does not supervise, employees will not implement the $5 \mathrm{~S}$ site management. In a limited time game, the result will not change. But in the long run, the company is expected to run indefinitely. So find the right measures to reward employees and implement $5 \mathrm{~S}$ site management is the right way.

2) Mixed Strategy Nash Equilibrium:

The expected utility function of the special team is:

$$
\begin{aligned}
U 1= & P(1-U)[V(-K+L 1)+(1-V)(1-W)(X-K+L 1) \\
& +(1-V) W(-K+X)]+P U[V(-K+L 1)+(1-V) \\
& (1-W)(-K)+(1-V) W(-K)]+(1-P)[V L 1+0+0] \\
& =P(1-U)[-K+(1-W+W V) L 1+(1-V) X]+P U \\
& (-K+V L 1)+(1-P) V L 1
\end{aligned}
$$

The first partial derivatives:

$$
\frac{\partial U 1}{\partial P}=0, V^{*}=1+\frac{K}{(U-1)[(1-W) L 1+X]}
$$

The expected utility function of employees is:

$$
\begin{aligned}
U 2= & V[P(1-U)(-C 0+L 0)+P U(-C 0+L 0)+ \\
& (1-P)(-C 0)]+(1-V)(1-W)[P(1-U)(-C 0-X) \\
& +P U(-C+L 0)+(1-P)(-C)]+(1-V) W[P(1-U) \\
& (-C-X)+P U(-C+L 0)+(1-P)(-C)] \\
& =V(P L 0-C 0)+(1-V) W[P(U-1)(C-C 0)]+ \\
& (1-V)[P(U-1)(C 0+X)+P U(L 0-C)+(P-1) C]
\end{aligned}
$$

The first partial derivatives:

$$
\begin{aligned}
& \frac{\partial U 2}{\partial V}=0, P^{*}=\frac{C 0-C}{(1-U)[L 0+X+(W-1)(C-C 0)]} \\
& \frac{\partial V^{*}}{\partial K}=\frac{1}{(U-1)[(1-W) L 1+X]}<0 \text { It indicates that in the }
\end{aligned}
$$

background of high cost, employees are not willing to implement the $5 \mathrm{~S}$ site management.

$$
\frac{\partial V^{*}}{\partial U}=\frac{-K}{(U-1)^{2}[(1-W) L 1+X]}<0 \quad \text { It indicates that }
$$

reduce the probability of mistaken obey the rule for not obey the rule may make employees to better implement the $5 \mathrm{~S}$ site management.

$$
\frac{\partial V^{*}}{\partial X}=\frac{-K}{(U-1)[(1-W) L 1+X]^{2}}>0 \text { It indicates that the }
$$

increase of punishment may make employees to better implement the $5 \mathrm{~S}$ site management.

$$
\frac{\partial P^{*}}{\partial W}=\frac{(C 0-C)^{2}}{[L 0+X+(W-1)(C-C 0)]^{2}(1-U)}>0 \text { It indicates }
$$

that the special team should strengthen the probability of active inspection especially employees refused to rectification.

$$
\frac{\partial P^{*}}{\partial U}=\frac{C 0-C}{[L 0+X+(W-1)(C-C 0)](1-U)^{2}}>0 \text { It indicates }
$$

that the high probability of mistaken obey the rule for not obey the rule need frequent inspection to make up.

\section{SUMMARY}

The implementation of $5 \mathrm{~S}$ site management is a continuous process. If we only implement once, we may cost more and reduce the benefits. The way of thinking is very important. The habit need to be formed to implement the $5 \mathrm{~S}$ site management. Leading should play the leading role. Frequent educational activities are needed. Corporate culture may form step by step. Continuous improvement is the way to promote the process of $5 \mathrm{~S}$ site management. Enterprises should not blindly criticize employees. Incentive mechanism should be improved. Then employees may have the power to implement the $5 \mathrm{~S}$ standard. There is no ending in $5 \mathrm{~S}$ site management. Only in this way can we reach Pareto optimal.

\section{ACKNOWLEDGMENT}

I would like to extend my sincere gratitude to professor Zhao for her instructive advice and useful suggestions on the research. I am deeply grateful of her help in the completion of this research. I will continue to work hard under her direction.

\section{REFERENCES}

[1] Li Pengxiang, The application of $5 \mathrm{~S}$ management in a building construction site, Shenyang University of Technology, 2013, In Chinese.

[2] Xing Lei, Application of 5S site management in A Boiler Company, Shandong University, 2013, In Chinese.

[3] Han Lijiao, Research on communication management of engineering project construction process based on Game Theory, North China Electric Power University, 2014, In Chinese.

[4] Yuan Taiping, Yuan Jianwen, Zhang Huaigang. "Discussion on the application of $5 \mathrm{~S}$ management in construction site of infrastructure project," China Power Enterprise Management,pp.1002-1003, 2014, In Chinese. 
[5] Guo Jianming, “Applicationof 5S Management in Power Grid Construction," Distribution \& Utilization , pp. 70-72, June 2015, In Chinese.
[6] Liu Wantao, "The application of game theory in the management of safety production," Inner Mongolia Coal Economy, pp. 19-20, August 2016, In Chinese. 